\title{
Marine boundary layer characteristics during a cyclonic storm over the Bay of Bengal
}

\author{
Savita B Morwal ${ }^{1}$, S G Nagar ${ }^{1}$, V S N Murty ${ }^{2, *}$ and P Seetaramayya ${ }^{1}$ \\ ${ }^{1}$ Indian Institute of Tropical Meteorology, Pune 411 008, India. \\ ${ }^{2}$ National Institute of Oceanography, Goa 403 004, India. \\ *e-mail: morwal@tropmet.res.in
}

\begin{abstract}
During the period 12-16 June 1996 a tropical cyclonic storm formed over the southwest Bay of Bengal and moved in a north-northeasterly direction. The thermodynamic characteristics of this system are investigated by utilizing the surface and upper air observations collected onboard ORV Sagar Kanya over the Bay of Bengal region. The response of the cyclonic storm is clearly evident from the ship observations when the ship was within the distance of $600-800 \mathrm{~km}$ from the cyclonic storm. This study explores why (i) the whole atmosphere from surface to $500 \mathrm{hPa}$ had become warm and moist during the cyclonic storm period as compared to before and after the formation of this system and (ii) the lower layer of the atmosphere had become stable during the formative stage of the cyclonic storm.
\end{abstract}

\section{Introduction}

A tropical cyclone is the most serious form of natural disasters, both in terms of loss of life and damage to property. Loss of life occurs mostly in coastal areas because the high winds of the cyclone raise the water level due to the generation of huge waves and inundate the coastal region. Cyclones also badly disrupt many socio-economic activities in these areas, such as, fishing, shipping, offshore oil rigging, etc. (Holt and Hunt 1997). Frank (1977) has documented the large-scale structure of the tropical cyclone in northwest Pacific based on 10 years rawinsonde data. From the schematic diagram of an idealized matured tropical cyclone, he has shown different convective regions depending on the radial distance $(r)$ from the eye of the cyclone. The inner region $\left(r=0-4^{\circ}\right)$ is characterized by intense convection and extremely strong cyclonic wind flow. Just outside from these strong convective areas, there is usually a relatively clear or 'moat' region $\left(r=4-6^{\circ}\right)$ with little or no intense convection. Beyond the moat region $\left(r \geq 6^{\circ}\right)$ convection approaches the mean tropical conditions.
It is well known that the frequency of occurrence of tropical cyclones is more over the Bay of Bengal (hereafter BoB) than over the Arabian Sea (Desai and Waikar 1997). It is also well known that during the pre-monsoon (April-May) and the post-monsoon (October-November) seasons, severe tropical cyclones form over the southern $\mathrm{BoB}$ within an area between $5-15^{\circ} \mathrm{N}$ and $85-90^{\circ} \mathrm{E}$. Sikka (1977), Rao (1987) and Rao et al (1993) have studied the structure and dynamics of the synoptic scale systems over the BoB. However, the vertical structure of the atmosphere over the $\mathrm{BoB}$ using the high resolution radiosonde data has not yet been studied due to paucity of data. Holt and Raman (1986) have examined the thermal structure of the marine boundary layer (MBL) over the $\mathrm{BoB}$ during active and break monsoon periods utilizing MONEX-79 dataset. Seetaramayya et al (1993) have studied the thermodynamic structure of the MBL in relation to a monsoon depression which formed in situ with its center at $20^{\circ} \mathrm{N}, 89^{\circ} \mathrm{E}$ during 18-21 August 1990. They have reported the importance of the boundary layer processes in the development and maintenance of tropical

Keywords. Cyclonic storm; marine boundary layer; thermodynamic structure; onset phase of monsoon; conserved variable diagrams. 
systems over the $\mathrm{BoB}$ region during the monsoon season.

Thus studies relating to the thermodynamic behaviour of pre-monsoon cyclones in the $\mathrm{BoB}$ region are meager due to the scarcity of marine radiosonde data during the formative stages of cyclones. An attempt has been made in this study to examine the changes in the thermodynamical characteristics of a cyclonic storm, which formed during the onset phase of summer monsoon 1996 over the BoB during 12 to 16 June 1996.

\section{Data}

A multidisciplinary cruise onboard ORV Sagar Kanya was organized by the National Institute of Oceanography (NIO), Goa and India Meteorological Department (IMD), New Delhi during the period 23 May to 18 June 1996. During this cruise, systematic routine radiosonde (RS) observations were taken by the IMD at 00 UTC (solid circle) and 12 UTC (star) at the locations shown in figure 1 . The RS ascents used in the present study are marked by a square around the solid circle/star in the figure. A comparison of the radiosonde ascents taken just before (26 May and 30 May, solid circle or star closed by an open triangle) and during the formation and developed stages (9 June and 15 June respectively, solid circle or star closed by a solid triangle) of the system indicates the thermodynamic properties of the marine atmosphere at different stages of the cyclone. The ship was located at $11^{\circ} 30^{\prime} \mathrm{N}, 88^{\circ} \mathrm{E}\left(30\right.$ May and 9 June) and $17^{\circ} 48^{\prime} \mathrm{N}$, $89^{\circ} \mathrm{E}$ (26 May and 15 June). This RS data set contains dry bulb and dew point temperatures, geopotential height at the interval of $50 \mathrm{hPa}$ from surface $(1000 \mathrm{hPa})$ up to $100 \mathrm{hPa}$. In the present study we have used the data from $1000 \mathrm{hPa}$ up to $500 \mathrm{hPa}$ for the period 8-18 June 1996 to understand the thermodynamic processes which take place prior to, during, and after the formation of the tropical cyclone during the period 8-18 June 1996. In addition to the above RS data the surface synoptic observations, surface synoptic charts (03 UTC) and the INSAT-1B satellite visible photo images are also consulted.

\section{Synoptic weather conditions}

Figure 2 shows the surface synoptic charts from 917 June 1996 at 03 UTC. From the figure it can be seen that a low pressure area formed along the southeast coast of India and the northern tip of Sri Lanka on 9 June 1996. This low pressure lay over Sri Lanka on 10 June and moved northwestward in the south $\mathrm{BoB}$ centered at $9^{\circ} \mathrm{N}$,

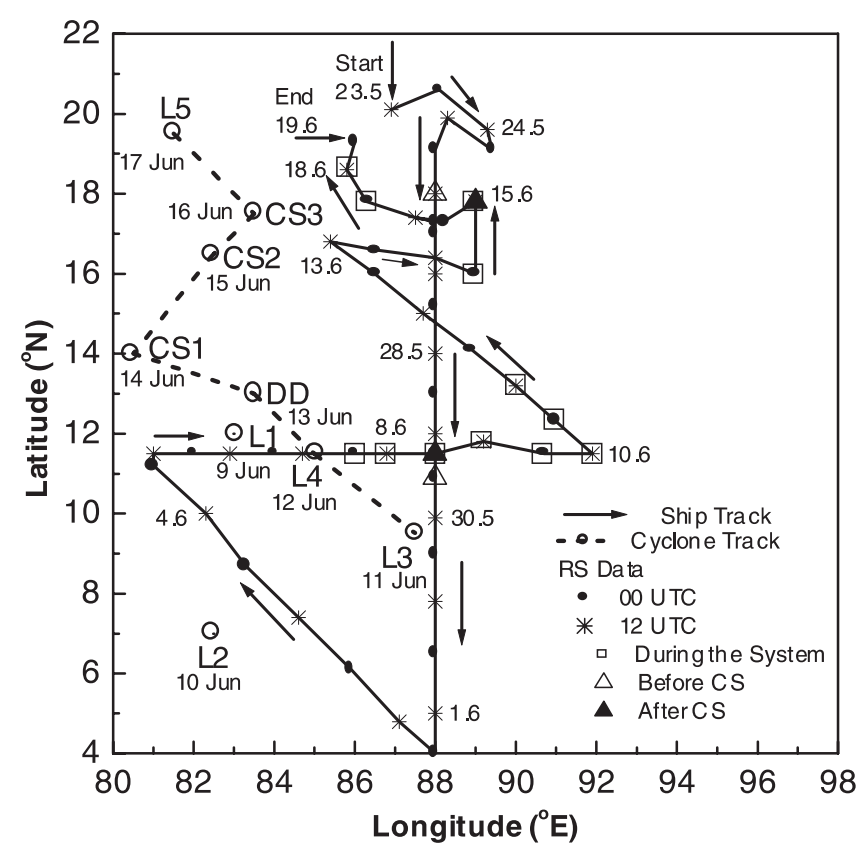

Figure 1. The tracks of the cruise ORV Sagar Kanya (solid line) and the cyclonic storm (dashed line). Solid circles (00 UTC) and stars (12 UTC) represent the radiosonde position. L: Low, DD: Deep Depression and CS: Cyclonic Storm. Dates are mentioned against some of the ship locations where RS ascents were taken and also for the different stages of the system.

$88^{\circ} 30^{\prime} \mathrm{E}$ on 11 June. It then shifted northwestward on 12 June and further intensified into a depression over the southeast and adjoining southwest $\mathrm{BoB}$ on the same evening (12 UTC). It intensified into a deep depression with its centre near $12^{\circ} 30^{\prime} \mathrm{N}, 83^{\circ} \mathrm{E}$ on 13 morning (03 UTC) and moved in a northwesterly direction and lay over the southwest BoB about $200 \mathrm{~km}$ east of Chennai on 13 evening (12 UTC). The system further intensified into a cyclonic storm by 14 morning (03 UTC) and lay centered near $14^{\circ} \mathrm{N}, 80^{\circ} 30^{\prime} \mathrm{E}$. It recurved in a north-northwesterly direction and lay about $70 \mathrm{~km}$ southeast of Kakinada on the morning of 15 June (03 UTC). The lowest estimated central pressure was $986 \mathrm{hPa}$ at $12 \mathrm{UTC}$ of 15 June 1996. The maximum wind speed reported at this stage was 60 $80 \mathrm{kmph}\left(16-22 \mathrm{~m} \mathrm{~s}^{-1}\right)$. Further, the system moved in a north-northeasterly direction and crossed the coast near Visakhapatnam around 05 UTC on 16 June. It weakened into a well-marked low pressure area over north Vidarbha and the neighbourhood by 16 June evening and lay over the southeast Madhya Pradesh at 03 UTC on 17 June. The track of the cyclonic storm is shown in figure 1 by a thick dashed line. The different stages associated with the intensification of the system from low (L, 9-12 June, 17 June) to cyclonic storm (CS, 14-16 June) through deep depression 


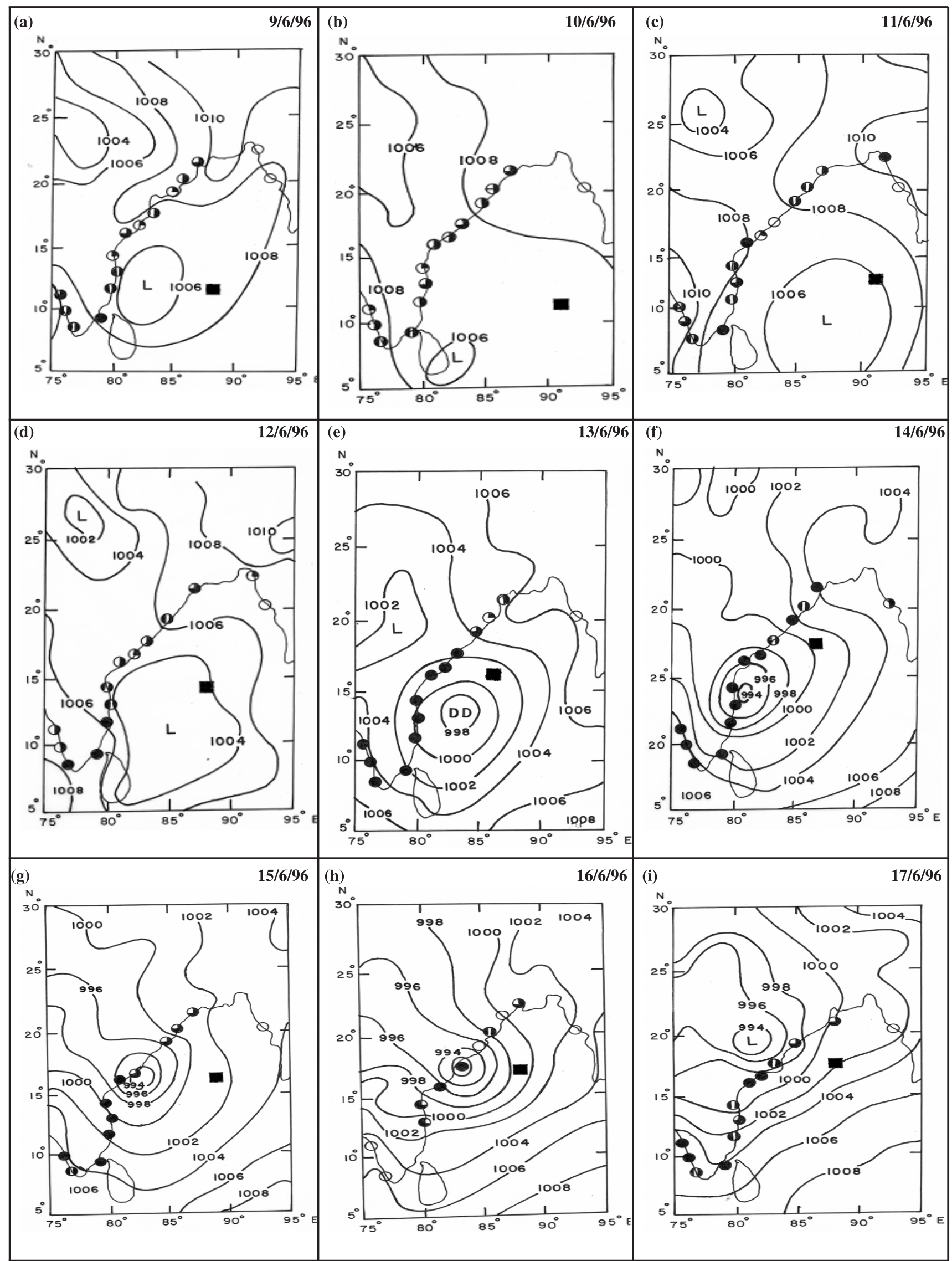

Figure 2. Surface synoptic charts during 9-17 June 1996 at 03 UTC. The ship position is marked by the symbol ( 


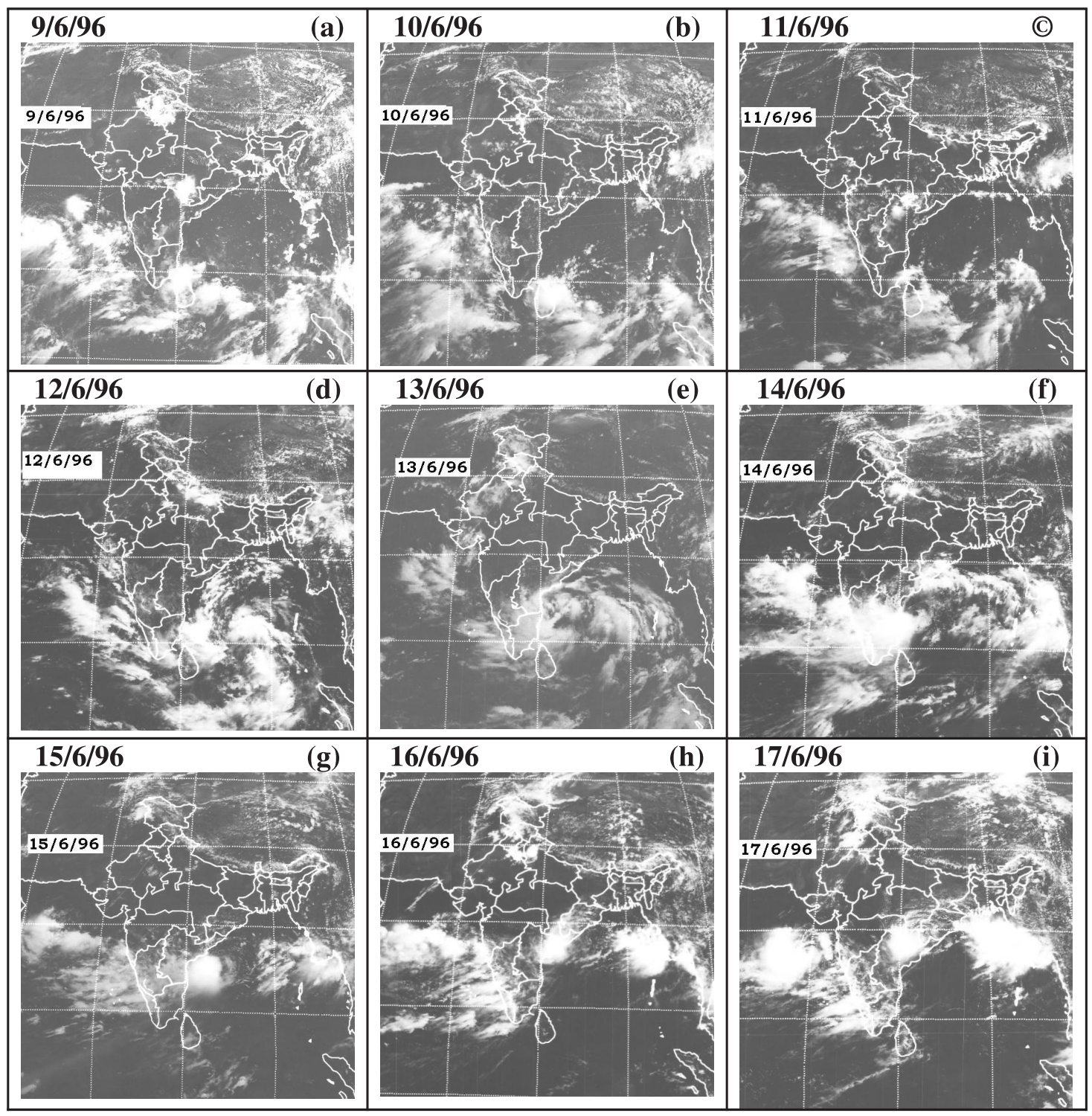

Figure 3. Satellite pictures during 9-17 June 1996 showing the life history of the cyclonic storm.

(DD, 13 June) are also indicated with corresponding date on this track as described above. Also, some of the days of observations are shown including starting (23.5) and ending (19.6) days of the cruise.

The INSAT-1B visible satellite pictures for the same days are shown in figure 3 . From these satellite imageries it can be seen that the observational area was cloud-free up to 11 June and dense clouds were seen from 12 to 16 June 1996. The maximum intensity of the system was T2.5 on Dvorak's scale from 15 evening to 16 morning. As the system moved over land the observational area had again become cloud-free on 17 June. Cyclone Detection Radar (CDR) at Madras had reported spiral bands on 14 June. CDR Machilipatnam and CDR
Visakhapatnam had also reported spiral bands on 16 June 1996.

\section{Natural disaster}

The coastal districts of Tamil Nadu and Andhra Pradesh reported very heavy rain of the order of 20 to $25 \mathrm{~cm}$ from 14 to 17 June 1996 . Koida, a station in Khammam district of Andhra Pradesh, reported a record rainfall of $67.5 \mathrm{~cm}$. The coastal districts of Andhra Pradesh reported 68 deaths. About 6000 houses were damaged. The estimated loss of crops was reported to be about Rs. 82 crores. In Tamil Nadu 41 persons were killed and 4 fishing vessels sank. Also road and rail traffic were badly affected. 


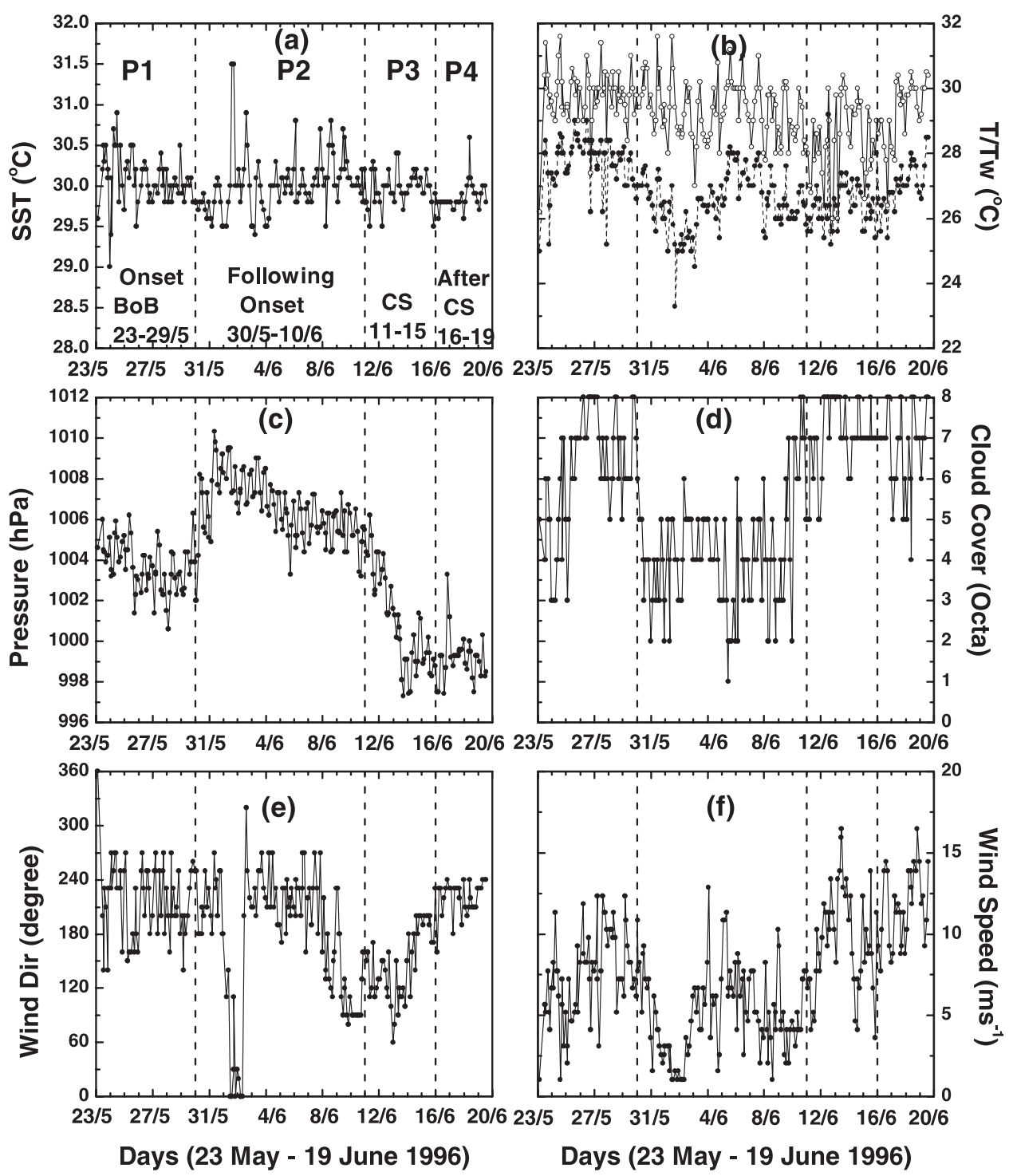

Figure 4. Time series of 3-hourly surface synoptic observations collected over ORV Sagar Kanya during 23 May to 19 June 1996. (a) Sea surface temperature (SST), (b) dry bulb $(T)$ and wet bulb $\left(T_{w}\right)$ temperature, (c) sea level pressure (SLP), (d) total cloud cover, (e) wind direction and (f) wind speed. The vertical dashed lines separate the four categories $(\mathrm{P} 1-\mathrm{P} 4)$ of various stages of the cyclonic storm.

\section{Results and discussion}

\subsection{Distribution of surface parameters}

Figure 4(a-f) shows the time series of 3-hourly data set of sea surface temperature (SST), air temperature $(T)$, wet bulb temperature $\left(T_{w}\right)$, sea level pressure (SLP), cloud cover, wind direction and wind speed from 23 May to 19 June 1996 over the area of observations. The period of observations is divided into 4 categories (P1-P4) based on the observed meteorological phenomena and are separated by vertical dashed lines in the figure:

- P1: 23 May-30 May associated with onset of southwest monsoon over BoB.
- P2: 30 May-11 June followed by onset of southwest monsoon over BoB and receded by cyclonic storm.

- P3: 11 June-16 June in which formation, development and intensification of the system was observed and

- P4: 16 June-19 June characterized by the post cyclonic period during which the CS had weakened and moved over land as low (L5 in figure 1).

From figure 4(a) it can be seen that SST showed a steady decreasing trend during onset period (P1). Following the onset it slightly decreased to $29.5^{\circ} \mathrm{C}$ and thereafter it was oscillating between $29.5^{\circ} \mathrm{C}$ and $30.9^{\circ} \mathrm{C}$ with a mean of $30^{\circ} \mathrm{C}$. During $\mathrm{P} 3$ also, the SST was oscillating around $30^{\circ} \mathrm{C}$ but 
the amplitude of oscillation was less in comparison to that of P2. After CS (P4) the SST was lower, ranging from $29.5^{\circ} \mathrm{C}$ to $30^{\circ} \mathrm{C}$.

From figure $4(\mathrm{~b})$ it can be seen that the dry bulb and wet bulb temperatures followed similar trends. The values of air temperature slightly decreased from $30^{\circ} \mathrm{C}$ to $29^{\circ} \mathrm{C}$ from $\mathrm{P} 1$ to $\mathrm{P} 2$. Diurnal variations are clearly seen in both the curves throughout the period. The dryness was maximum in P2 as compared to the other three periods. In the beginning of P3 the air temperature reduced to $26^{\circ} \mathrm{C}$ (13 June, $00 \mathrm{UTC}$ ) and then increased abruptly to $30.4^{\circ} \mathrm{C}$ (13 June $09 \mathrm{UTC}$ ). This type of sudden fall $\left(26.6^{\circ} \mathrm{C}\right.$ on 14 June 2100 UTC) and abrupt increase $\left(29.4^{\circ} \mathrm{C}\right.$ on 15 June 0300 UTC) was also observed on 15 June. In the wake of CS (P4) the temperature regained its value of $30.5^{\circ} \mathrm{C}$.

Figure 4(c) shows the time series of SLP. It shows an increasing trend from 27 May to 1 June during P1 (in accordance with climatology) due to southward motion of the ship along $88^{\circ}$ E. From 1 June onwards the SLP started decreasing from $1010 \mathrm{hPa}$ to $1004.2 \mathrm{hPa}$ on 10 June during P2. A steep decrease in pressure was observed during P3 with its lowest value of $997 \mathrm{hPa}$ on 13 June 12 UTC. Similar low values were observed on 13 June 21 UTC and 14 June 00 UTC. As the SST increased, the storm intensified more rapidly and attained a lower minimum surface pressure (DeMaria and Pickle 1988). It rapidly increased to $1000 \mathrm{hPa}$ on the same day at 06 UTC. On this day, the ship was about $700 \mathrm{~km}$ away from the CS1 (figure 1) in the northeast sector. During P4 the SLP increased from $997 \mathrm{hPa}$ at $09 \mathrm{UTC}$ to $1003.3 \mathrm{hPa}$ at $15 \mathrm{UTC}$ of 16 June. After this the SLP was oscillating between 997.5 and $1000 \mathrm{hPa}$.

During the onset phase the ship experienced the cloud amount varying between 3 and 8 octa, following onset it varied between 2 and 6 octa (figure $4 d$ ). Further, most of the time the sky was overcast during P3 and P4. Figure 4(e) shows southeasterly to westerly winds with speed varying $1-12 \mathrm{~ms}^{-1}$ during P1 (figure 4f). It decreased rapidly following onset (P1) up to $1 \mathrm{~ms}^{-1}$ during $\mathrm{P} 2$, rapidly increased to $13 \mathrm{~m} \mathrm{~s}^{-1}$ within 2-3 days with northwesterly direction. Thereafter, it showed a decreasing trend up to 10 June which increased up to $16 \mathrm{~m} \mathrm{~s}^{-1}$ in the northeasterly direction on 13 June. It decreased rapidly to $4 \mathrm{~ms}^{-1}$ within a day and then a continuous increasing trend was seen up to 18 June $\left(15 \mathrm{~m} \mathrm{~s}^{-1}\right)$ in southerly to southwesterly direction.

Figure 5 shows the SSMI (Special Sensor Microwave Imageries) sea surface winds on 11 June 1996 at 00 UTC in which an incipient convergence zone was clearly seen at $9^{\circ} 30^{\prime} \mathrm{N}, 87^{\circ} \mathrm{E}$ in the formative stage. The figure clearly emphasizes the northsouth wind shear (strong westerly on the southern
SSMI Sea surface winds : 11069600 UTC

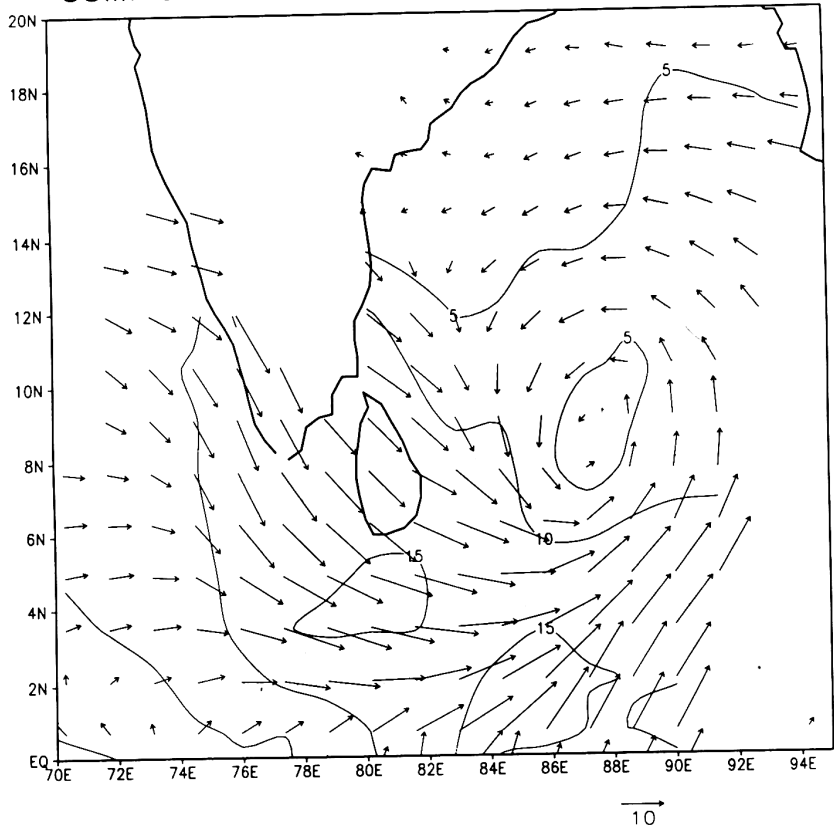

Figure 5. SSMI sea surface winds on 11 June 1996 at 00 UTC.

side and weak easterly on the northern side) and east-west wind shear (northerly on western side and southerly on eastern side), which are centered around the convergence zone. These strong horizontal wind shears which are favourable for low level convergence are necessary for intense development of the system.

\subsection{Thermodynamic structure}

The thermodynamical parameters such as virtual potential temperature $\left(\theta_{v}\right)$, mixing ratio $(q)$, equivalent potential temperature $\left(\theta_{e}\right)$ and saturated equivalent potential temperature $\left(\theta_{e s}\right)$ have been computed from the vertical profiles of air temperature and dew point temperature using standard formulae (Bolton 1980; Morwal 1998).

To quantify the variability in temperature $(T)$ and relative humidity $(\mathrm{RH})$ vertical profiles of $T$ and $\mathrm{RH}$ of all the radiosonde ascents during 23 May-18 June 1996 over the ship at 00 and 12 UTC are shown in figure 6 (a and b) respectively. Figure 6(a) shows that the temperature variability at the surface is less $\left(<4^{\circ} \mathrm{C}\right)$ as compared to higher levels. It varies between 8 and $9^{\circ} \mathrm{C}$ in the layer 1.5 $3.0 \mathrm{~km}$ and at the other remaining levels the variability is between 6 and $7^{\circ} \mathrm{C}$. Figure $6(\mathrm{~b})$ shows large variability in $\mathrm{RH}$ at all the levels. The range of variability is $25-88 \%$; the minimum (maximum) being at the surface $(5.0 \mathrm{~km})$. The variability in temperature and $\mathrm{RH}$ is both due to differences among the individual radiosondes and the influence 

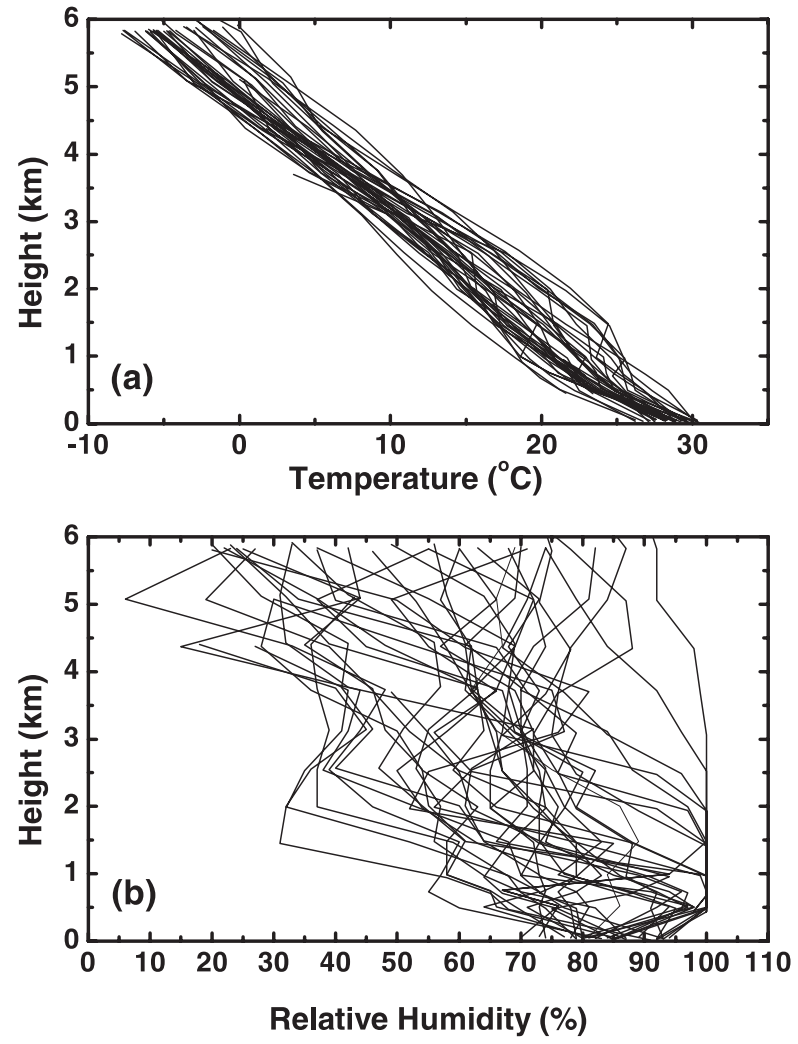

Figure 6. Vertical profiles for radiosonde ascents over the ship during 23 May-18 June 1996 for 00 and 12 UTC. (a) Temperature and (b) relative humidity.

of different stages of the cyclonic system over the ship.

The vertical profiles of $\theta_{v}, \theta_{e}, \theta_{e s}$ and $q$ for some selective days viz., $8-11,15$ and 18 June for 00 and 12 UTC are shown in figures 7 and 8 respectively. The profiles of 8-10 June are taken along the same latitude, i.e., $11^{\circ} 30^{\prime} \mathrm{N}$ but at different longitudes at $00\left(86^{\circ} \mathrm{E}, 88^{\circ} \mathrm{E}, 90^{\circ} 42^{\prime} \mathrm{E}\right)$ and $12 \mathrm{UTC}$ $\left(86^{\circ} 48^{\prime} \mathrm{E}, 89^{\circ} 12^{\prime} \mathrm{E}, 91^{\circ} 54^{\prime} \mathrm{E}\right)$. On these days the low pressure area over the Bay lay to the southwest (near Sri Lanka) of the observational positions (vide figures $2 \mathrm{a}$ and $2 \mathrm{~b}$ ). Further, the profiles on 11,15 and 18 June have been taken at $12^{\circ} 18^{\prime} \mathrm{N}$, $91^{\circ} \mathrm{E}, 16^{\circ} \mathrm{N}, 89^{\circ} \mathrm{E}, 17^{\circ} 48^{\prime} \mathrm{N}, 86^{\circ} 18^{\prime} \mathrm{E}$ (00 UTC) and $13^{\circ} 12^{\prime} \mathrm{N}, 90^{\circ} \mathrm{E}, 17^{\circ} 48^{\prime} \mathrm{N}, 89^{\circ} \mathrm{E}, 18^{\circ} 36^{\prime} \mathrm{N}, 85^{\circ} 48^{\prime} \mathrm{E}$ (12 UTC) respectively. On 11 June (figure 2c) the low pressure area became well marked and lay in the south-central BoB. On 15 June, the system was along the east coast at Visakhapatnam as a severe cyclonic storm (figure 2g) and on 18 June it dissipated after moving over the land. Thus the profiles on 8-10 June and 18 June are representative of the prevailing atmospheric conditions before and after formation of the cyclonic storm respectively. The profiles for 11 and 15 June are associated with the observed cyclonic circulation during formative and intensified stages of the cyclone respectively.

In figure 7 , it is seen that $\theta_{v}$ is almost conserved (Betts 1982), constant with height in the sub-cloud layers (1000-900 hPa) indicating a near neutral atmosphere. It is stable thereafter above $900 \mathrm{hPa}$ with a gradual increase in $\theta_{v}$ from $8-11$ June. But on 15 and 18 June, it shows complete stable conditions right from 950 to $500 \mathrm{hPa}$ (surface data not available on these days). The $q$ profiles indicate the gradual decrease from surface up to higher levels. To infer the convective activity, profiles of $\theta_{e}$ and $\theta_{e s}$ have been used (Betts and Albrecht 1987). From $\theta_{e}$ profiles it is seen that the atmosphere is convectively unstable in the lower layers $\left(\partial \theta_{e} / \partial z<0\right)$ prior to the formation of cyclone (8-10 June). During the formative and intensification stages (11-15 June) and after the movement of cyclonic storm over land, the low level instability decreases. The unstable mid levels on 8 June become neutral on 10 June. The moist static energy represented by $\theta_{e}$ curve shows nearly neutral conditions from surface up to $600 \mathrm{hPa}$ at all the points of observations during 11-18 June.

The dashed straight lines in the figures indicate a constant $\theta_{e}$ path of the ascending non-entraining air parcel from $980 \mathrm{hPa}$ (the mean LCL height). The difference between the constant $\theta_{e}$ path of the parcel and the $\theta_{e s}$ of the sounding is proportional to the temperature difference between the parcel and its environment. If $\theta_{e}$ of the $980 \mathrm{hPa}$ parcel path is greater than $\theta_{e s}$ of the sounding above the LCL, but intersects the $\theta_{e s}$ profile at a pressure greater than $600 \mathrm{hPa}$ the sounding is classified as an inversion sounding. If the $980 \mathrm{hPa}$ parcel is positively buoyant above the LCL to at least $600 \mathrm{hPa}$ level the sounding is generally associated with deep convection. If the low level parcel is negatively buoyant below $600 \mathrm{hPa}$ level the sounding represents shallow convection (Kloesel and Albrecht 1989). On the basis of this classification the soundings on 8,11 , 15 and 18 are classified as deep convective soundings, whereas the soundings of 9 and 10 June are classified as inversion soundings. It is observed that the level of free convection (point of intersection of environmental $\theta_{e s}$ curve and constant $\theta_{e}$ line) has risen from $900 \mathrm{hPa}$ on 9 June to $750 \mathrm{hPa}$ on 10 June.

From $\theta_{v}$ profiles for 12 UTC (figure 8) it is observed that the atmosphere is stable from surface up to higher levels $(\sim 500 \mathrm{hPa})$ on 11 and 15 June whereas it is nearly neutral in the lower layers (up to $900 \mathrm{hPa}$ ) on 8-10 and 18 June (i.e., before and after the passage of the cyclonic storm). In the lower layers the convective instability is more before and after the cyclone (as seen from $\theta_{e}$ profiles on $8-10$ and 18 June) and it is convectively 


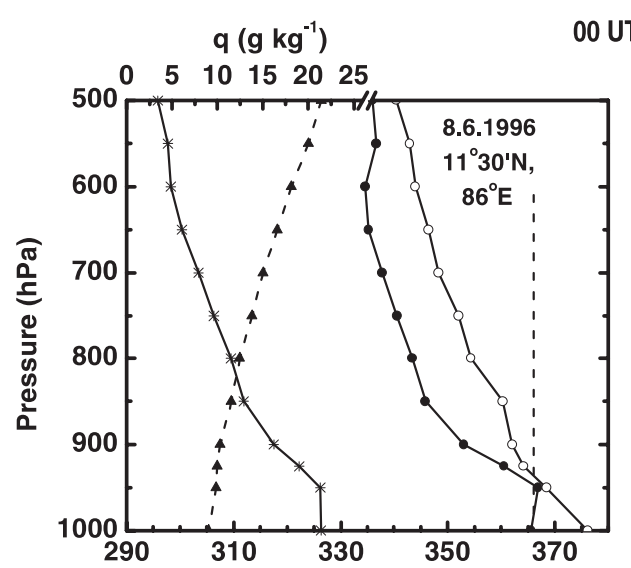

$\quad \mathrm{q}\left(\mathrm{g} \mathrm{k} \mathrm{k}^{-1}\right)$
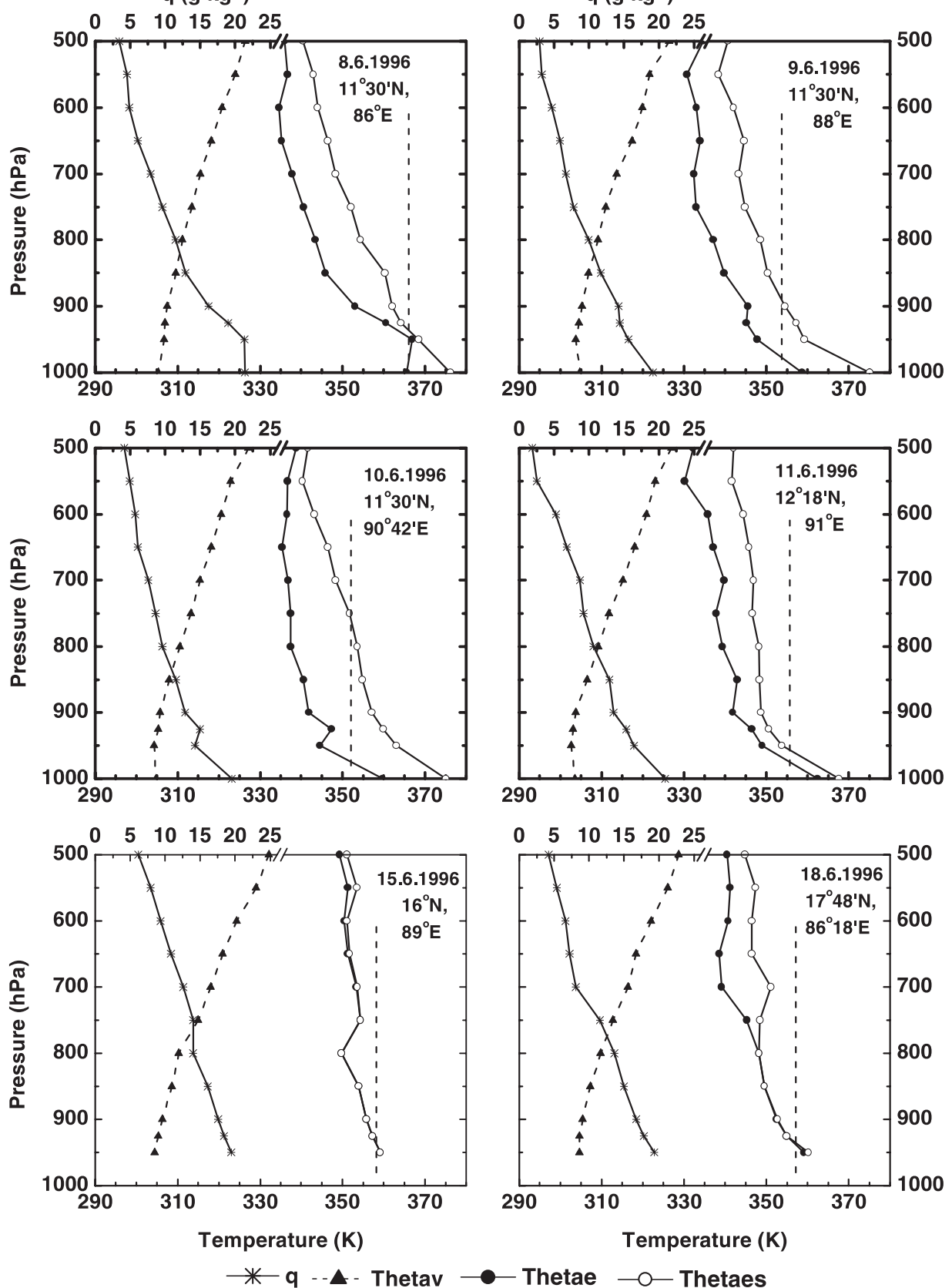

Figure 7. Vertical profiles of Theta $v\left(\theta_{v}\right)$, Theta $e\left(\theta_{e}\right)$, Theta $e s\left(\theta_{e s}\right)$ and $q$ at 00 UTC during 8-18 June 1996.

stable on 11 and 15 June. The moist static energy (i.e., $\left.\theta_{e}\right)$ is nearly constant in mid levels $(700-$ $550 \mathrm{hPa}$ ) on 10 June. The layer of constant $\theta_{e}$ is from $800-500 \mathrm{hPa}$ (depth $\sim 300 \mathrm{hPa}$ ) on 11 June and 15 June. This layer descends down to 950-800 hPa (depth $\sim 150 \mathrm{hPa}$ ) on 18 June after the cyclone crosses the coast at Visakhapatnam (16 June). DeMaria and Pickle (1988) have also observed similar features over western Pacific and concluded that moist mid levels generally favour more intense and more rapidly developing storms. On the basis of the classification made using $\theta_{e}, \theta_{e s}$ and constant $\theta_{e}$ line all the soundings are classified as deep convective soundings at 12 UTC.

The conserved variable diagrams $\left(\theta_{e}-q\right)$ at 00 UTC (solid line with open circle) and 12 UTC (dashed line with solid circle) are shown in figure $9(\mathrm{a}-\mathrm{f})$. The number near the symbol represents the level (in $\mathrm{hPa}$ ) of that point. Figure 9 (a) shows $\theta_{e}-q$ diagrams during the passage of the system on 9 June when the ship was about $550 \mathrm{~km}$ east of the centre of the low (L1 in figure 1). Though the values of $\theta_{e}$ and $q$ at the surface remain the same at 00 and 12 UTC of 9 June, the increase 


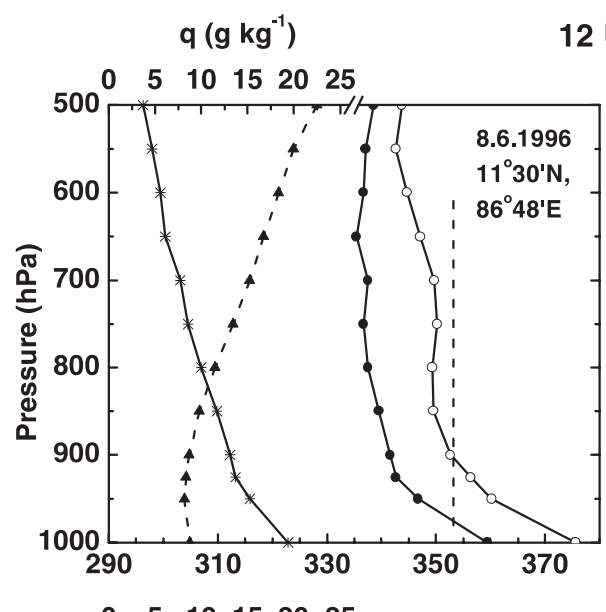

12 UTC $\quad q\left(\mathrm{~g} \mathrm{~kg}^{-1}\right)$

$\begin{array}{llllll}0 & 5 & 10 & 15 & 20 & 25\end{array}$
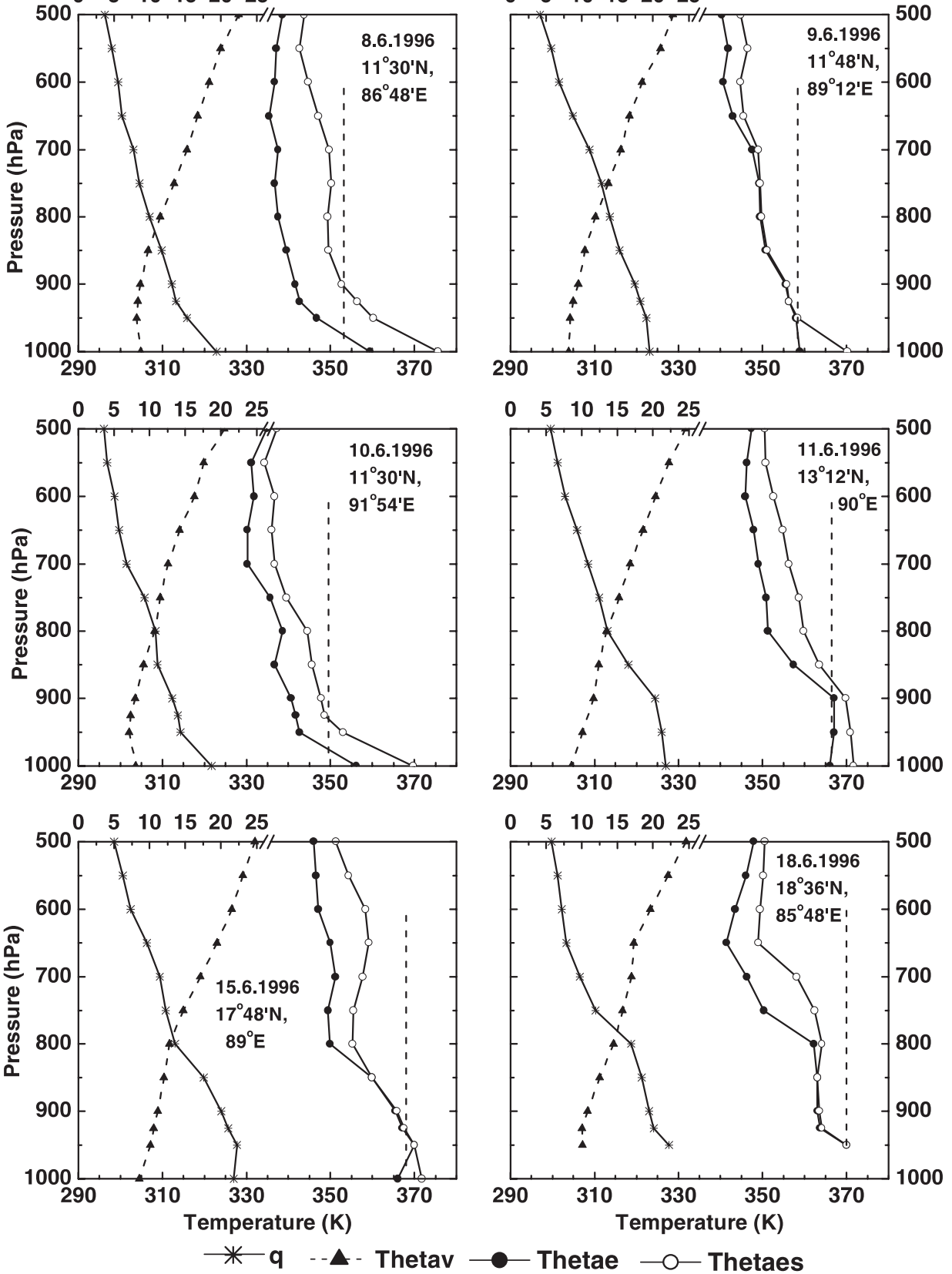

Figure 8. Same as figure 7 but for 12 UTC.

of $6-12 \mathrm{~K}$ in $\theta_{e}$ and $1-6 \mathrm{~g} \mathrm{~kg}^{-1}$ in $q$ is observed in the upper levels from 00 to 12 UTC. On the morning of 10 June (figure 9b) the ship was around $950 \mathrm{~km}$ east-northeast of the prevailing low (L2) and this distance was about $1050 \mathrm{~km}$ at 12 UTC on the same day. The atmosphere had become cooler by $1-14 \mathrm{~K}$ (being more in the lower levels) and dry by $1-5 \mathrm{~g} \mathrm{~kg}^{-1}$ (more in lower levels) from $12 \mathrm{UTC}$ of 9 June to 00 UTC of 10 June. This difference in the atmospheric conditions may possibly be due to the movement of the ship away from the disturbed area (i.e., low). On the same day (10 June) when the ship had further moved by $100 \mathrm{~km}$ in the same direction the atmosphere had cooled by $1-4 \mathrm{~K}$ and dried by $1-2 \mathrm{~g} \mathrm{~kg}^{-1}$ at the same levels. This cooling may be due to cloudy conditions prevailing over the ship as shown in figure 4. On 11 June (figure 9c) the centre of the low had shifted from L2 $\left(7^{\circ} \mathrm{N}, 82^{\circ} 30^{\prime} \mathrm{E}\right)$ to $\mathrm{L} 3\left(9^{\circ} 30^{\prime} \mathrm{N}, 87^{\circ} 30^{\prime} \mathrm{E}\right)$ at $03 \mathrm{UTC}$. The location of the ship was $450 \mathrm{~km}$ northeast of L3. The atmosphere had become warm by $2-5 \mathrm{~K}$ and moist by $1-3 \mathrm{~g} \mathrm{~kg}^{-1}$ from 12 UTC of 10 June 

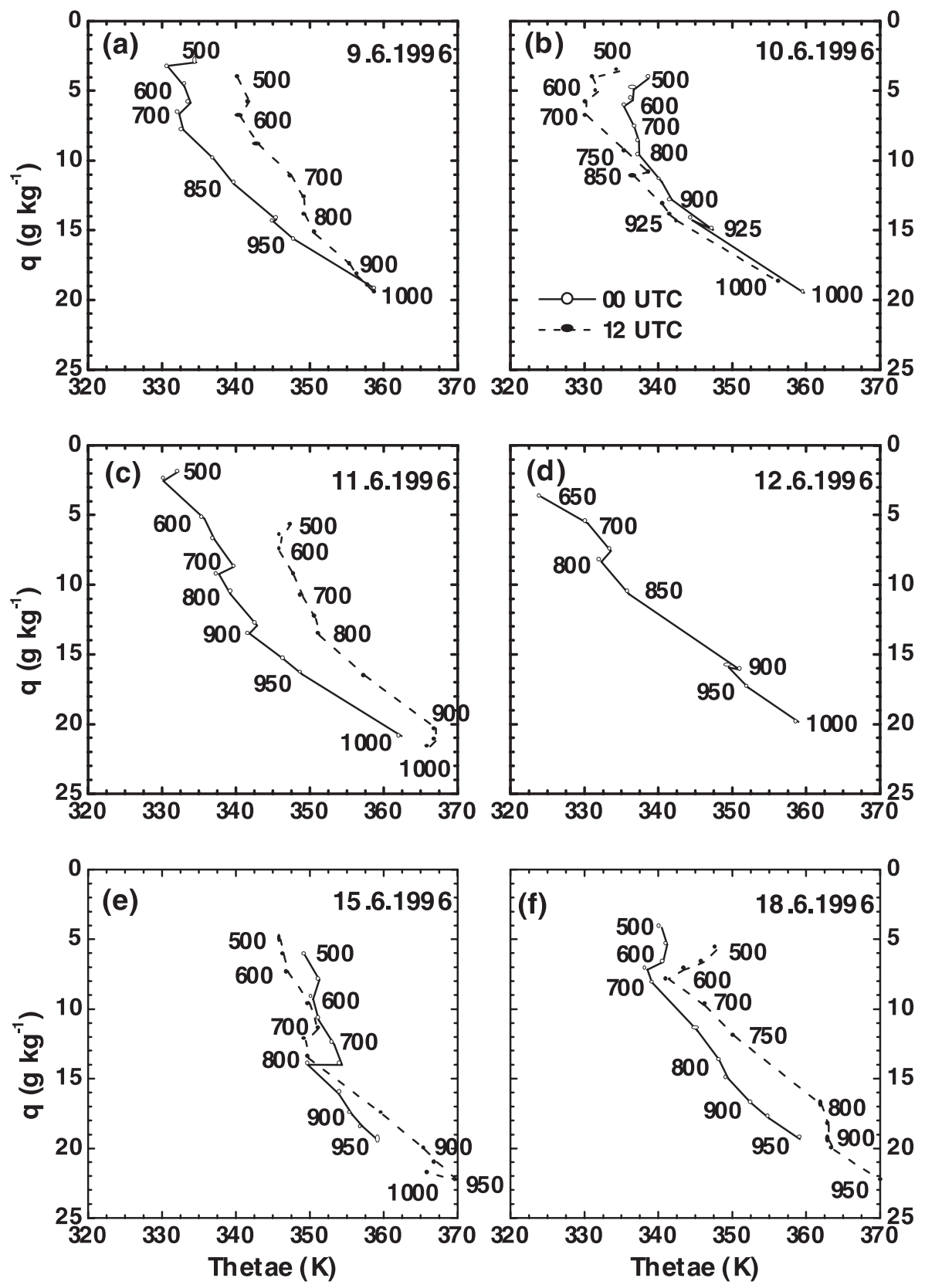

Figure 9. Conserved variable diagrams $\left(\theta_{e}-q\right)$ at 00 and 12 UTC during 9-18 June 1996. The corresponding heights (in $\mathrm{hPa})$ are given near the respective points.

to 00 UTC of 11 June (except in the higher levels). The atmosphere had become warmer by $10-25 \mathrm{~K}$ and more moist by $2-6 \mathrm{~g} \mathrm{~kg}^{-1}$ from 00 UTC of 11 June to 12 UTC of the same day. This warming may possibly be the influence of the prevailing low pressure area as the ship was now in the periphery of the low.

On 12 June (00 UTC) the ship had moved further northwest and was about $440 \mathrm{~km}$ away from the system (L4 in figure 1) in the northeast direction. Considerable changes were observed in the atmosphere. The surface cooled by $7 \mathrm{~K}$ (figure $9 \mathrm{~d}$ ) and this cooling was around $20 \mathrm{~K}$ between 850 and
$650 \mathrm{hPa}$ from $12 \mathrm{UTC}$ of 11 June to $00 \mathrm{UTC}$ of 12 June. At the same time the whole atmosphere dried by $3-5 \mathrm{~g} \mathrm{~kg}^{-1}$ which could be attributed to the subsidence over this region. When compared with the sounding of 00 UTC of 11 June it was observed that the atmosphere was warmer and drier on 12 June (00 UTC) below $850 \mathrm{hPa}$ (except at the surface) and vice versa in the upper layers.

The observations were not available when the low intensified into deep depression (DD) on 13 June and cyclonic storm (CS1) on 14 June. On 15 June when the cyclonic storm (CS2) had its centre at $16^{\circ} 30^{\prime} \mathrm{N}, 82^{\circ} 30^{\prime} \mathrm{E}$, the ship was (towards 
the eastern side) approximately $740 \mathrm{~km}$ away from CS2. It is observed from figure $9(\mathrm{e})$ that the atmosphere was warmer $(3-7 \mathrm{~K})$ and more moist $\left(2-3 \mathrm{~g} \mathrm{~kg}^{-1}\right)$ below $800 \mathrm{hPa}$ and cooler and drier above $800 \mathrm{hPa}$ at $12 \mathrm{UTC}$ as compared to $00 \mathrm{UTC}$. At $800 \mathrm{hPa}$ the conditions remain unchanged. The system weakened to low (L5) on 17 June and moved westward towards the land. The locations of ship were very close to each other on 18 June 00 and 12 UTC. The atmosphere was warmer by $\sim 10 \mathrm{~K}$ and more moist by $2-4 \mathrm{~g} \mathrm{~kg}^{-1}$ up to $500 \mathrm{hPa}$ at 12 UTC as compared to 00 UTC (figure 9f).

It is interesting to note from these $\theta_{e}-q$ curves that a single mixing line structure is observed on 9 and 18 June, i.e., before and after the passage of the system whereas, double mixing line structure is seen on 10-15 June (except 11 June 12 UTC). This double mixing line structure is mainly due to pumping up of moisture upwards by deep convection and the horizontal advection of moisture in the mid-levels. Further $\theta_{e}-q$ curves for 12 UTC indicate cool and dry conditions on 10 June and warm and moist conditions in the lower layers (surface $-900 \mathrm{hPa}$ ) on 11 and 15 June. In general, the atmosphere is warm and moist during 11 and 15 June as compared to 9, 10 and 18 June (the difference in $\left.\theta_{e}>10 \mathrm{~K}\right)$. Due to this difference of warm and moist conditions there exists deep convection during 11 and 15 June which had led to the cyclogenesis in this region.

\subsection{Comparison of profiles before and during formative stages}

To highlight the changes in the boundary layer characteristics at a particular location before and during the formative/developed stage of the cyclonic storm, two locations have been selected. Figure $10(\mathrm{a}-\mathrm{c})$ shows the profiles of $\theta_{v}, q$ and conserved variable diagram $\left(\theta_{e}-q\right)$ near about $11^{\circ} \mathrm{N}$, $88^{\circ} \mathrm{E}$ for the days 30 May 1996 (before, solid line with open circle) and 9 June 1996 (during formative stage, dashed line with solid circle). It can be seen from figure $10(\mathrm{a})$ that there is not much significant change in $\theta_{v}$ between these two days, but it is slightly lower on 9 June than on 30 May, because the monsoon had already advanced at this location on 28 May 1996. However, below $750 \mathrm{hPa}$ the moisture is more and above $750 \mathrm{hPa}$ it is less before the formation of the system and vice-versa during the formative stage on 9 June (figure 10b) due to horizontal advection of moisture. Multiple cloud layers are observed as indicated by the $\theta_{e}$ minima (shown by arrows in figure 10c). In this figure the corresponding heights (in $\mathrm{hPa}$ ) are indicated by different sizes for before (large size) and during (small size in Italics) the formative stage of the system. The same notation is followed in figure 11(c)
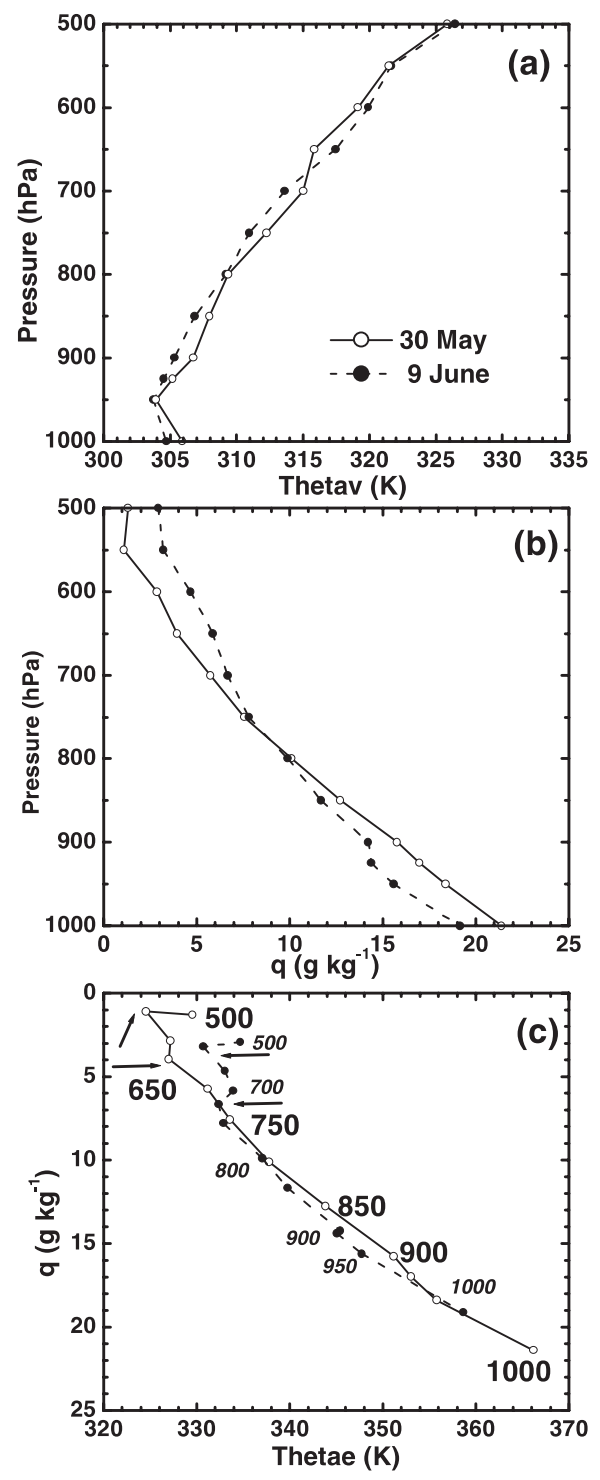

Figure 10. Profiles of (a) Theta $v\left(\theta_{v}\right)$, (b) $q$ and (c) $\theta_{e}-q$ for 30 May and 9 June at $11^{\circ} \mathrm{N}, 88^{\circ} \mathrm{E} 00$ UTC. The corresponding heights (in $\mathrm{hPa}$ ) are indicated by different sizes for May (large size) and June (small size in Italics).

also. The mixing lines on $\theta_{e}-q$ profiles (figure 10c) indicate single mixing line structure on both the days.

Figure $11(\mathrm{a}-\mathrm{c})$ shows profiles of $\theta_{v}, q$ and conserved variable diagram $\left(\theta_{e}-q\right)$ near about $18^{\circ} \mathrm{N}$, $88^{\circ} \mathrm{E}$ for the days 26 May 1996 (before) and 15 June 1996 (intensified phase of the storm). From figure $11(\mathrm{a})$ it can be seen that the atmosphere is unstable in the lower levels up to $950 \mathrm{hPa}$ and stable aloft on 26 May when the monsoon has not yet arrived at this location. Therefore the air mass at this location, which was cold and dry on 26 May, has been modified into warm (figure 11a, except at the surface) and moist (figure 11b) during the developed stage (15 June) at all levels. In the lower layers the convective instability shows 

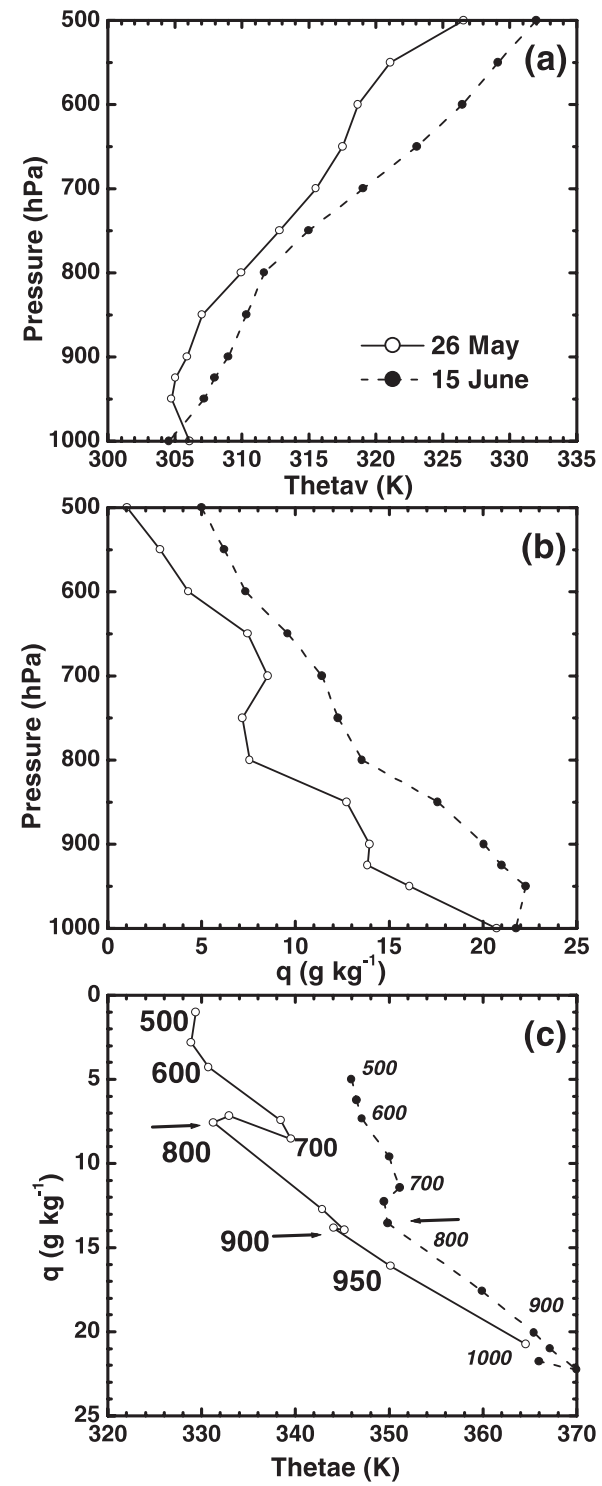

Figure 11. Profiles of (a) Theta $v\left(\theta_{v}\right)$, (b) $q$ and (c) $\theta_{e}-q$ for 26 May and 15 June at $18^{\circ} \mathrm{N}, 88^{\circ} \mathrm{E} 12$ UTC. The corresponding heights (in $\mathrm{hPa}$ ) are indicated by different sizes for May (large size) and June (small size in Italics).

a decrease as the system developed into cyclonic storm and the atmosphere became convectively stable. Multiple cloud layers with dry air in midlevels (not conducive for any convective activity) are observed on 26 May, whereas the whole atmosphere indicates moist convective activity on 15 June. Double mixing line structure (kinks in $\left(\theta_{e}-q\right)$ diagrams, figure 11c) is observed on 26 May, which indicates mixing of two air masses of different characteristics representing the presence of cloud masses. The mixing ratio increases in between the two cloud layers because of ascending and descending motions in the two clouds. Thus the sounding on 26 May is representative of the fair weather cumulus clouds. On 15 June such prominent kinks are not observed because of the prevalent nearly-homogeneous atmosphere from surface up to $500 \mathrm{hPa}$ levels.

\section{Conclusions}

A cyclonic storm (CS) was formed over the Bay of Bengal during 12-16 June 1996. The thermodynamic properties of the lower troposphere in this cyclonic field have been examined at some selected locations in the Bay of Bengal using the surface synoptic data and the radiosonde data collected onboard ORV Sagar Kanya during the period 23 May to 18 June 1996.

The response of the CS is clearly evident from the ship observations when the ship was within the distance of $600-800 \mathrm{~km}$ from the CS. The surface $\theta_{e}$ values are in the range of $350-370 \mathrm{~K}$ which are conducive for the deep convection in the Bay of Bengal. The corresponding range of $\theta_{e}$ over the warm pool of the Pacific Ocean is $345-365 \mathrm{~K}$ (Betts and Ridgway 1989; Kingsmill and Houze 1999). The observations showed a slight stable value of SST $\left(29.5-30.5^{\circ} \mathrm{C}\right)$, abrupt decrease in air temperature $\left(26^{\circ} \mathrm{C}\right)$, increase in moisture (decrease in difference between $T$ and $T_{w}$ ), sudden drop in SLP $(997.5 \mathrm{hPa})$, overcast skies (7-8 octa) and increase in wind speed $\left(16 \mathrm{~m} \mathrm{~s}^{-1}\right)$ in southeasterly direction. After the passage of the CS, air temperature regained to $30^{\circ} \mathrm{C}$ whereas, other parameters did not show sudden changes.

The thermodynamic parameters have revealed that the whole atmosphere from surface to $500 \mathrm{hPa}$ became warm and moist during cyclonic storm period (11 to 15 June) as compared to that before the formation of CS and after its weakening. The lower boundary layer was neutrally stratified before and after the system whereas, this layer became stable during the formative stage of the cyclonic storm. Horizontal and north-south wind shears over the warm water region $\left(29-30^{\circ} \mathrm{C}\right)$ in the southcentral Bay of Bengal region on 11 June are clearly depicted in the SSMI sea surface winds during the initial formative stage. These wind shears seem to act as an initial triggering mechanism for the cyclogenesis to occur at $9^{\circ} 30^{\prime} \mathrm{N}, 87^{\circ} \mathrm{E}$ over warm waters $\left(\geq 30^{\circ} \mathrm{C}\right)$. Significant modifications in the marine atmospheric thermodynamic conditions are observed in the presence of cyclonic storm.

\section{Acknowledgements}

The authors are thankful to Dr. G B Pant, Director, IITM, Pune and Dr. Elgar Desa, Director, 
NIO, Goa for their constant encouragement of scientific interactions between IITM and NIO. We gratefully thank the India Meteorological Department, New Delhi for supplying the above data. Thanks are also due to Shri R M Khaladkar for giving us the SSMI wind data. The authors are also thankful to an anonymous referee for constructive comments and suggestions which were useful for the improvement of the paper.

\section{List of symbols and abbreviations}

$\begin{array}{ll}\theta_{v} & \begin{array}{l}\text { Virtual potential temperature } \\ (\text { Theta } v)\end{array} \\ \theta_{e} & \begin{array}{l}\text { Equivalent potential temperature } \\ (\text { Theta } e \text { ) }\end{array} \\ \theta_{e s} & \begin{array}{l}\text { Saturated equivalent potential tem- } \\ \text { perature (Theta } e s)\end{array} \\ q & \text { Specific humidity or mixing ratio } \\ \text { LCL } & \text { Lifting Condensation Level } \\ \text { SST } & \text { Sea Surface Temperature } \\ \text { L } & \text { Low } \\ \text { DD } & \text { Deep Depression } \\ \text { CS } & \text { Cyclonic Storm } \\ \text { BoB } & \text { Bay of Bengal } \\ \text { BOBMEX } & \text { Bay of Bengal Monsoon Experiment }\end{array}$

\section{References}

Betts A K 1982 Saturation point analysis of moist convective overturning; J. Atmos. Sci. 39 1484-1504.

Betts A K and Albrecht B A 1987 Conserved variable analysis of the convective boundary layer thermodynamic structure over the tropical ocean; J. Atmos. Sci. 44 83-99.
Betts A K and Ridgway W 1989 Climatic equilibrium of the atmospheric convective boundary layer over a tropical ocean; J. Atmos. Sci. 46 2621-2641.

Bolton D 1980 The computation of equivalent potential temperature; Mon. Wea. Rev. 108 1046-1053.

DeMaria M and Pickle J D 1988 A simplified system of equations for simulation of tropical cyclones; J. Atmos. Sci. 45 1542-1554.

Desai D S and Waikar B D 1997 Recurving cyclonic storm during 1970-94; Mausam 48 421-428.

Frank W A 1977 The structure and energetics of the tropical cyclones I: Storm Structure; Mon. Wea. Rev. 105 $1119-1135$.

Holt M W and Hunt J C R 1997 Prediction of sea state under tropical cyclones in the UK Met Office operational global wave model; Mausam 48 621-628.

Holt T and Raman S 1986 Observations of the mean and turbulence structure of the marine boundary layer over the Bay of Bengal during MONEX-79; Mon. Wea. Rev. $1142176-2190$

Kingsmill D E and R A Houze Jr 1999 Thermodynamic characteristics of air flowing into and out precipitating convection over the West Pacific warm pool; Quart. J. Roy. Meteor. Soc. 125 1209-1229.

Kloesel K A and Albrecht B A 1989 Low level inversions over the tropical Pacific-thermodynamic structure of the boundary layer and the above-inversion moisture structure; Mon. Wea. Rev. 117 89-101.

Morwal S B 1998 Nature and some evolutionary aspects of the monsoon boundary layer; Ph.D. Thesis, University of Pune, Pune.

Rao R R 1987 Further analysis on the thermal response of the upper Bay of Bengal to the forcing of pre-monsoon cyclonic storm and summer monsoonal onset during MONEX-79; Mausam 38 147-156.

Rao R R, Mathew B and Hareeshkumar P V 1993 A summary of results on thermohaline variability in the upper layers of the East Central Arabian Sea and Bay of Bengal during summer monsoon experiments; Deep-Sea Res. 40 1647-1672.

Seetaramayya P, Parasnis S S, Nagar S G and Vernekar K G 1993 Thermodynamic structure of the boundary layer in relation to monsoon depression over the Bay of Bengal A case study; Bound.-Layer Meteorol. 65 307-314.

Sikka D R 1977 Some aspects of the life history, structure and movement of monsoon depression; Pure Appl. Geophys. 115 1501-1529. 